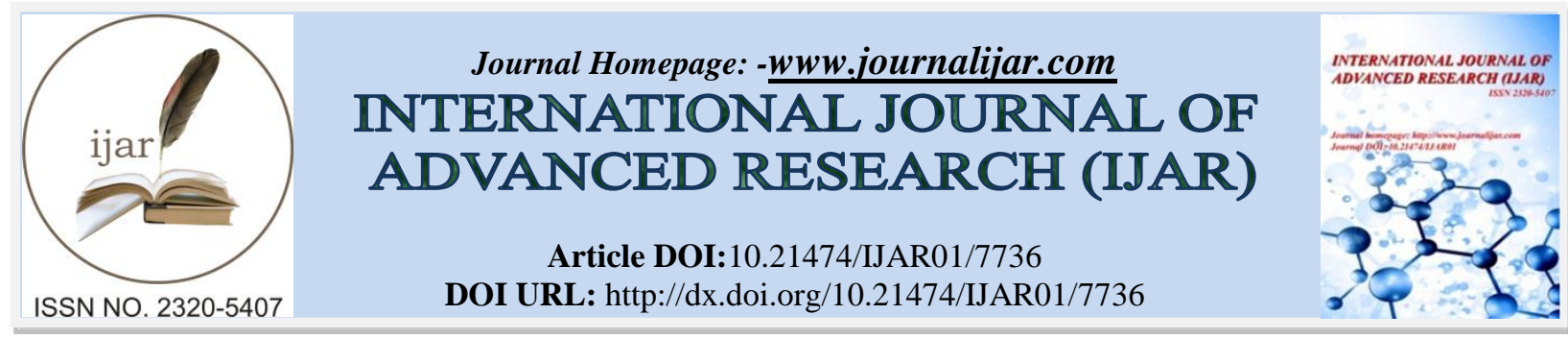

RESEARCH ARTICLE

\title{
THE STRATEGIES FOR ENHANCING TOURISM SMES' COMPETITIVENESS:THE CHALLENGES FACING THAILAND TOURISM SECTOR UNDER THE AEC'S LIBERALIZED TRADE IN SERVICES.
}

\section{Pornphatu Rupjumlong, D.P.A., Anatchai Rattakul, Ph.D., Kwanming Khumprasert,Ph.D. And Piphat Kovitkanit, Ph.D.}

1. Advisor, ASEAN and Asia Studies Center, and Lecturer, Graduate School of Public Administration National Institute of Development Administration.

2. Committee Member of National Education CouncilDirector of Public Policy and Management Center, Kasem Bundit University.

3. Lecturer, General Management Program, Faculty of Management Science Phranakhon Radjabhat University

4. Director, Maruay Garden Hotel.

\section{Manuscript Info}

Manuscript History

Received: 23 July 2018

Final Accepted: 29 August 2018

Published: September 2018

Keywords:-

Tourism, SMEs, Competitiveness,

Challenge, AEC's liberalized trade in services.

\begin{abstract}
The AEC's liberalization of trade in services brings ample opportunities and higher competition. This paper is a documentary research, adopting a meta-analysis method and narrative approach, focusing on tourism SMEs' roles, their weakness, strength, threat, opportunities, and challenges. The findings revealed the strength of Thailand's rich tourism resources, good tourism infrastructures, and strong tourism brand, which depended on the government's management. Tourism SMEs' strength was their entrepreneurship and warm hospitality, and the weakness was the lack of the access to finance and technology, poor human capital development, managerial skills, value creation and innovation capability. A key challenge was the higher competition. Recommendations are that proactive strategies, based on the tourism competitiveness factors, should be adopted with sustainability principles to ensure no present and future socioeconomic, political and environmental impacts on local communities and the overall national tourism. The personnel having AEC and tourism knowledge, and ICT well-trained staffs are also required and must be empowered for enhancing tourism SMEs' competitiveness.
\end{abstract}

Copy Right, IJAR, 2018,. All rights reserved.

\section{Introduction:-}

The travel and tourism contributed $9.5 \%$ of the world GDP in 2013, or 7 trillion US dollar, and created around 4.7 million new jobs or 1 in 11 jobs worldwide, supporting 266 million people in employment (World Travel and Tourism Council, 2014: 3). Tourism is a significant economic drive as it offers a significant potential for economic growth and development. It creates job and generates stable income, as well as promotes cultural heritage and traditions (World Economic Forum, 2013: 64). Tourism involves dual economic structure (Keller, 2004): the travel and tourism industry, in which large companies provide travel and tourism related services, and the destinationoriented services and activities which are mostly dominated by SMEs, therefore the destination competitiveness reflects the tourism SMEs' competitiveness.

Corresponding Author:- Pornphatu rupjumlong.

Address:- Advisor, ASEAN and Asia Studies Center, and Lecturer, Graduate School of Public 
Tourism plays a significant role to Thailand economy. The United Nations World Tourism Organization (UNWTO) revealed that in 2013 Thailand had 26.5 international tourist arrival, ranked the tenth of the world top ten international tourist arrival, and earned 42.1 billion USD of international tourism receipts, ranked the seventh of the world top ten international receipt (UNWTO, 2014: 6-7), hitting the highest record. The tourism SMEs providing servicesat a tourism destination play significant roles in representing the destination image as they deliver services and tourism experience to the tourists/visitors with personal touch. The tourism SMEs' competitiveness, which relates to the tourism destination competitiveness, significantly contributes to Thailand tourism growth and sustainability.

The pressure of globalization has a major impact on tourism SMEs along with rising competition due to a number of emerging new destinations (Smeral, 1998) in the region. It is necessary to have the tourism SMEs' competitiveness enhanced to ensure that they will be capable to cope with the change, and be competitive amid the higher competition.

A tourism destination attracted visitors for various reasons; natural resources, climate, and tourists seek experience based on local identity and culture (UNWTO, 2012). The development of local destination depended on what the place had to offer: different destinations have different attractions. People travelled to a destination for different reasons: to explore, participate, understand, see, and learn something of the destination's socio-cultural fabric and experience (Crouch and Ritchie, 2003). The tourist-friendly hospitality of the locals and local tourism SMEs give visitor memorable experience and bring about the repeated visit.

Thailand has been recognized as a world class destination due to the Thai people's warm hospitality, rich natural resources: sandy beach, climate; Alias Sea, Sun, Sand (3S). In addition, the tourism activities and resources, created by human, such as the cultural and historic heritage, narratives, Thai food and the sense of Thai taste also contribute to Thailand's tourism reputation. Another aspect of utmost importance for the tourists' holiday experience was the cuisine of the destination (UNWTO, 2012). Thailand has a variety of good food available around the clock.

Tourism is unique by its nature as the tourists' experience comprises not just the tourism resources, but the local people's attitude and hospitality. The local tourism destination stakeholders, the host community, tourism SMEs, as well as individual tourism service providers play significant roles in rendering memorable experience and tourism services to the tourists.

During 2012-2013 the Organization of Economic Co-operation and Development (OECD) revealed that there were about 2.9 million SMEs, or 99.8\% of the overall enterprises in Thailand, and 975,552 SMEs, or 99.8\%, were in the service sector (OECD, 2011, ASEAN, 2011). In 2008 SMEs contributed 39\% of the total Thai GDP (OECD, 2011). The aforesaid figures reflected only the number of enterprises having been officially registered, but there are a larger number of small enterprises and individuals who have actually rendered tourism services at local destinations.

The definitions of SMEs according to the SMEs Promotion Act, B.E. 2543 were as follows: a small enterprise referred to an enterprise having not more than 50 employees and fixed assets value not over 50 million Thai Baht, and a medium-sized enterprise referred to an enterprise having between 51-200 employees and fixed assets value over 50 to 200 million Thai Baht. Definitions of SMEs in other ASEAN member countries varied, for example Malaysia classified an enterprise having not over 5 employees as a micro-enterprise for both the service and manufacturing sector (Thailand Management Association, 2013). The re-categorization of SMEs to be promoted was discussed and agreed by the Office of Small and Medium Enterprise Promotion of Thailand (Royal Thai Government, 2014), but no amendment to the above-mentioned law had been made yet.

ASEAN (2013) recognized SMEs' roles as vehicles to generate and restore growth in their own country and the region. SMEs get involved in the tourism supply chain through business-to-business relationships and direct transactions with customers or tourists. SMEs' tourism activities and services include local ground handling, transport, accommodation, gastronomy, food and beverage, local travel services, excursions and activities, entertainment, shopping, community-based tourism services, creative tourism products and services, MICE facilities service providers, waste disposal and recycling services.

The SMEs' roles at a destination include the following: 1) supporting services: local ground handling, the travel and tourism services, and transport, 2) the key tourism services and activities: accommodation, entertainment, 
food/gastronomy, medical and wellness services, shopping, fundamental tourism services and supplementary services, and 3) a diversity of destination-oriented services of the natural, cultural and historic based tourism, creative and innovative tourism products/services, special interest tourism, and MICE facilities and supporting services: eco-socio cultural tourism.

The tourism SMEs play significant roles in destination-oriented services and activities and the tourism destination competitiveness directly relates to the tourism SMEs' competitiveness, and likewise. The government plays significant roles in tourism infrastructure development, maintenance and management of cultural, historic and natural tourism resources, in addition to the tourism governance, and policy making and implementation.

The tourism industry was dynamic as it was influenced by dynamic imperatives; with new customers or tourists, new practice, technologies, tourism management techniques, higher competitions and changes in the tourism industry's conditions (Poon, 1993). The climate and environmental conditions have impacts on climate-sensitive destination competitiveness and sustainability. A significant challenge in the tourism industry is the higher competition, and the customers' change of life style and behavior.

Another challenge was the human capital development (Asian Development Bank Institute, 2014) and the lack of skilled human resources in the travel and tourism. Tourism requires skilled human resources to cater a memorable experience to customers/tourists. The Royal Thai government also addressed the significance of human capital in the government policy statement, delivered by Prime Minister Gen Prayuth Chan-ocha in September 2014, and stressed that the quality of labor would be enhanced (Royal Thai Government,2014).

The crisis management requires the government's planning and efficient proceedings. The government's roles are significant to build good understanding and confidence in the safety of visitors, especially after crises. For the private sector, the main challenges include the higher competition, adaptability to change, quality services, development of skilled and quality human resources, and tourism product innovation.

\section{Methodology:-}

The objectives of this study are as follows: 1) to study the challenges, and weakness, strength, opportunities and threat to tourism SMEs in Thailand, 2) to find elements of tourism competitiveness, and 3) to propose strategies for enhancing tourism SMEs' competitiveness in response to the challenges amid rising competition due to the AEC's liberalized trade in services.

This paper is a documentary research, based on meta-analysis method (Egger and Smith, 1997), and the narrative approach (Glass, 1976; Glas, McGaw and Smith, 1981; Rosenthal, 1991a; Rosenthal and Rubin, 192, cited in Marzano, 1998). The researchers conducted the literature review of official ASEAN related documents, the Organization for Economic Co-operation and Development's (OECD) Studies on SMEs and Entrepreneurship, as well as academic researches, relevant information from reliable sources, scholarly articles, journals and newspapers. The SWOT analysis of tourism SMEs was conducted, based on Porter's five force competitive conceptual framework (Porter, 2008). The World Economic Forum's Travel and Tourism Competitiveness Index of the year 2013 and 2014 were analyzed, and compared among the ASEAN member countries. The OECD's key elements of competitiveness in tourism (OECD, 2013) were studied to find out elements of the tourism competitiveness. The findings were logically synthesized, categorized and analyzed. The outcomes were organized, based on the cognitive system (Marzano, 1998), and the knowledge was utilized in making strategies for enhancing the Thai tourism SME's competitiveness.

\section{Findings and Conclusions:-}

\section{The SWOT Analysis of Thailand Tourism SMEs}

The authors studied and analyzed the strength, weakness, opportunities and threats of Thailand tourism sector and SMEs, based on porter's five force competitive conceptual frameworks. The Table 1 and 2 on the next pages are summary on Thailand Tourism SMEs' SWOT analysis. Thailand tourism sector had suffered due to the internal factors, including the severe flood in Bangkok and the central region in 2012, political unrest during 2012 to early 2014, and the bombs blast in the middle of August 2015. 
The strength of Thailand tourism lied in the rich of natural tourism resources, good tourism infrastructures, and the strong Thailand tourism brand. Thailand safety and security was claimed poor, but most visitors to Thailand enjoyed their trouble-free time in Thailand, and there was 65 percent repeat tourist arrivals to Thailand.

Table 1:-Thailand Tourism SMEs' SWOT

\begin{tabular}{|c|c|}
\hline Strength & Characteristics: internal factors \\
\hline 1. Resources: & $\begin{array}{l}\text { Rich tourism resources: natural, biodiversity, Sea, Sun, Sand(3S), } \\
\text { eco-tourism destination, cultural heritage, traditions, art and crafts, climate, geographic } \\
\text { location (Ritchie and Couch, 2003) }\end{array}$ \\
\hline 1.1 Products & $\begin{array}{l}\text { Diverse tourism destinations/products, health/wellness tourism: } \\
\text { Thai spas, medical tourism (Rupjumlong, 2009) }\end{array}$ \\
\hline 1.2 Gastronomy & $\begin{array}{l}\text { Variety of good food: authentic Thai cuisine, street food stalls, } \\
\text { exotic seasonal fruits }\end{array}$ \\
\hline 2. Hospitality & $\begin{array}{l}\text { Warm hospitality: Thainess: gentle Thai touch, Thai smiles, service-minded human } \\
\text { resource (Ascot and Bermard, 2009, quoted in Rupjumlong,2009) }\end{array}$ \\
\hline 3. Human capital & $\begin{array}{l}\text { Strong affinity-friendly attitude towards tourists, (World Economic Forum, 2013), Thai } \\
\text { SMEs' high level of entrepreneurship (OECD,2012) }\end{array}$ \\
\hline $\begin{array}{l}\text { 4. Tourism } \\
\text { infrastructures }\end{array}$ & $\begin{array}{l}\text { Good infrastructures, ranked the first in ASEAN (World Economic Forum, 2013), access } \\
\text { to the destinations, good aviation access of international standard, good transport: air, } \\
\text { land and water }\end{array}$ \\
\hline 5. Tourism brand & $\begin{array}{l}\text { Strong Thailand tourism brand: one of the World Top Ten rank in } 2013 \text { for international } \\
\text { tourist arrivals and tourism receipts (UNWTO,2014) }\end{array}$ \\
\hline $\begin{array}{l}\text { 6. Government } \\
\text { support }\end{array}$ & $\begin{array}{l}\text { Thai government's recognition of tourism significance and support to SMEs (Royal Thai } \\
\text { Government, 2014), visa regulatory requirements waiver for certain nationals, e.g. the } \\
\text { Chinese, for a fixed period to promote the international tourist arrival }\end{array}$ \\
\hline
\end{tabular}

\begin{tabular}{|c|c|}
\hline Weakness & Characteristics: internal factors \\
\hline 1. Finance & $\begin{array}{l}\text { Lack of finance (OECD, 2012) for investment, and business expansion, little access to } \\
\text { financial facilities (Department of Tourism, 2012, Rupjumlong, 2009) }\end{array}$ \\
\hline $\begin{array}{l}\text { 2. Human capital/ } \\
\text { resources }\end{array}$ & $\begin{array}{l}\text { Human capital development: lack of skill base, trained human resource, knowledge } \\
\text { management, qualified labor, labor migration, poor English language and comprehension } \\
\text { skill, and poor knowledge of other languages (Department of Tourism 2012, } \\
\text { Rupjumlong, 2009), lack of access to resource and information (Sriburi,2007) }\end{array}$ \\
\hline 3. Management & $\begin{array}{l}\text { Managerial skills, adaptability, poor networking, ICT access (Department of Tourism, } \\
\text { 2012) little knowledge about ASEAN, and lack of experience in oversea investment }\end{array}$ \\
\hline 4. Tourism products & $\begin{array}{l}\text { Limited tourism products innovation (Department of Tourism, 2012), lack of destination } \\
\text { value creation (Braun,2004) }\end{array}$ \\
\hline $\begin{array}{l}\text { 5.Competitiveness/ } \\
\text { rivalry }\end{array}$ & High competition, lack of competitiveness enhancement (Choibamroong, 2014) \\
\hline $\begin{array}{l}\text { 6. Governance/ } \\
\text { government }\end{array}$ & $\begin{array}{l}\text { - Political instability, safety and security, lack of tourism crisis management strategies } \\
\text { - Inadequate government prioritization of tourism: inadequate distribution of resources } \\
\text { and workforce to certain sub-sectors (Wattanakuljarus et. al., 2014), and lack of monetary } \\
\text { support to tourism SMEs, inadequate measures on destination management } \\
\text { - Lack of cooperation on policies and lack of agencies, empowered to directly and } \\
\text { thoroughly implement tourism policies (Rupjumlong, 2009) }\end{array}$ \\
\hline
\end{tabular}


Table 2:-Thailand Tourism SMEs' SWOT Analysis

\begin{tabular}{|l|l|}
\hline \multicolumn{1}{|c|}{ Opportunities } & \multicolumn{1}{c|}{ Characteristics: external factors } \\
\hline 1. Digital technologies/ ICTs & $\begin{array}{l}\text { Use of digital technologies, and ICT to increase efficiency and improve } \\
\text { communication (Noel, et al., 2010) for wider market access, business management, } \\
\text { and marketing promotion, (Kotler,2006) }\end{array}$ \\
\hline $\begin{array}{l}\text { 2. Increasing regional } \\
\text { connectivity's and integrated } \\
\text { market }\end{array}$ & $\begin{array}{l}\text { Greater opportunities for tourism SMEs: improvement of intra- regional } \\
\text { transportation and tourism infrastructure, increasing } \\
\text { FDI in tourism sector, increasing equality of tourism HR, higher mobility of } \\
\text { tourism professional intra-regional (ASEAN,2008) }\end{array}$ \\
\hline 3. Government/ governance & $\begin{array}{l}\text { Greater governments' cooperation, policy coordination, prioritization of SMEs' } \\
\text { competitiveness, young entrepreneurs, vocational education and training (Royal } \\
\text { Thai Government, 2014), greater administrative procedure reform, better } \\
\text { improvement of intra-regional transportation and tourism infrastructure (ASEAN, } \\
\text { 2008) }\end{array}$ \\
\hline $\begin{array}{l}\text { 4. Integrated destination } \\
\text { branding }\end{array}$ & $\begin{array}{l}\text { Stronger tourism destination brand for the greater growth of tourism, increasing } \\
\text { international tourists arrivals: intra-ASEAN } \\
\text { and intra- Asia, and domestic demand tourists (Wong, et al., 2009), with greater } \\
\text { potential business network for SMEs }\end{array}$ \\
\hline
\end{tabular}

\begin{tabular}{|l|l|}
\hline \multicolumn{1}{|c|}{ Threats } & \multicolumn{1}{c|}{ Characteristics: external factors } \\
\hline 1. Vulnerability/ rivalry & $\begin{array}{l}\text { - Higher degree of openness (Asian Development Bank Institute, 2014), increasing } \\
\text { competition, lack of information on AEC liberalization in trade and services, insufficient } \\
\text { knowledge and preparedness for the change and challenges, potential job loss, higher } \\
\text { migration of skilled human resources (Department of Tourism,2012), } \\
\text { - Increasing competition by larger multi-national firms: stronger rivalries within local and } \\
\text { regional destinations }\end{array}$ \\
\hline $\begin{array}{l}\text { 2. Management } \\
\text { capability/ natural } \\
\text { disaster }\end{array}$ & $\begin{array}{l}\text { Climate change: tourism SMEs' vulnerability to the tourism hindrance disruption of } \\
\text { energy supply andfood security, crisis andrisk management, epidemic outbreak impacts, } \\
\text { deterioration of tourism resources and environment. }\end{array}$ \\
\hline $\begin{array}{l}\text { 3. Global and regional } \\
\text { economy/politics }\end{array}$ & $\begin{array}{l}\text { Economic turndown in countries, being significant tourism markets, } \\
\text { e.g. Russia and China, economic and political impacts on tourism SMEs; currency } \\
\text { fluctuation, war, terrorism }\end{array}$ \\
\hline $\begin{array}{l}\text { 4.Government/ } \\
\text { governance }\end{array}$ & $\begin{array}{l}\text { - Domestic regulatory and socio-political constraints } \\
\text { Political instability, safety and security, (World Economic Forum, 2013), natural } \\
\text { disaster: government's inadequate planning for crisis management } \\
\text { - Greater financial aid to SMEs by the government of other ASEAN member countries, } \\
\text { e.g. Singapore and Malaysia (Thailand Management Association, 2012) }\end{array}$ \\
\hline
\end{tabular}

The Thai tourism SMEs' strength was their entrepreneurship and warm hospitality, and their key weakness was the lack of access to finance and technology, poor human capital development, managerial skills, value creation and innovation capability.

The services and activities at a local tourism destination are mostly dominated by tourism SMEs, and the SMEs competitiveness significantly relates to the destination competitiveness. Competitiveness referred to the set of institutions, policies and factors, determining the productivity level, and the level of productivity, in turn, set the country's prosperity level (World Economic Forum, 2015). The destination competitiveness linked to the destination's ability, especially the local tourism SMEs' capability to deliver goods and services, which performed better than other destinations, and the aspects of tourism experience were deemed important by the tourists (Dwyer and Kim, 2003).

The OECD member countries currently consist of 34 countries in Europe, North and South America and Asia-Pacific (OECD, n.d.). Thailand has not been a member, though. The OECD members have strong travel and tourism competitiveness Spain ranked the first out of 141 countries globally (World Economic Forum, 2015), France ranked the second, Germany-the third, United States-the fourth, United Kingdom-the fifth, Switzerland-the sixth, Australia-the 
seventh, Italy-the eighth, Japan-the ninth, and Canada-the tenth. The authors reviewed the OECD member countries' tourism competitiveness to find out elements of destination competitiveness so that the outcomes be used in proposing the strategies for enhancing the tourism SMEs' competitiveness.

A tourism destination's competitiveness is a destination's ability to attract visitors with quality, attractive and innovative tourism services by providing good value-for money services to gain tourism market shares, domestically and globally, (OECD, 2013) while ensuring sustainable use of the tourism resources (Dupeyras and MacCullum N.2013).

\section{Elements of Tourism Competitiveness}

The tourism competitiveness elements defined by the Organization for Economic Co-operation and Development (OECD, 2013) comprise the following key elements: 1) destination accessibility/ connectivity: infrastructure, geostrategic position and proximity, 2) destination branding: destination awareness, appeal breadth, identity image, market diversification, promotion and marketing, 3) tourism governance: prioritization of tourism, government support, tourism strategy, safety and data, budget allocation, institutions (e.g. national tourism board), multilateral cooperation, 4) human resources development: education and training, skill, labor productivity, tourism training centers, 5) natural and cultural: biodiversity, climate, gastronomy, sustainability, 6) price competitiveness: prices, exchange rates, ratio price/quality or the value-for money, 7) tourism product development; product differentiation, innovation, investments, market share, unique experience provision, increased value added tourism, high value segments development, tourism marketplace perspective (inclusive of prospective travelers, tourism operators and small businesses, and 8) quality of tourism services: quality improvement, hospitality, quality of life, social equity and cohesion, and services to the customers.

For the destination competitiveness, Richie andCrouch (2003) concluded that the primary elements of destination appeal, or core resources and attractions were as follows: 1) physiography and climate, 2) culture and history, 3) market ties, ethnic ties, visiting friends and relatives (VFR) business, religion, sport, trade and cultural tie, 4) mix of activities, 5)special events, 6) entertainment, and 7) tourism superstructure; accommodation facilities, food services, transportation facilities and major attractions.

Richie and Crouch (2003) further added that the supporting factors and resources, which helped support the foundation of a tourism destination, mostly dominated by SMEs, included the following: 1) infrastructure: transportation services, sanitation system, communication systems, public facilities, a reliable and potable water supply, legal systems, and other tourism facilities, 2) enterprise: entrepreneurship and initiatives in developing new ventures in a destination, 3) accessibility: a supporting factor subject to economic, social or political concerns, 4) hospitality: warm acceptance, enabling visitors to believe they are welcome, and 5) political will: political support, inclusive of all community leaders' attitudes toward the tourism development.

The elements of tourism competitiveness, compiled from our studies as shown on table 3 on page 10 reflected the relations of the tourism SMEs' activities, would be used in making the strategies for enhancing tourism SMEs' competitiveness.

The World Economic Forum's Travel and Tourism Competitiveness Index is also reviewed as it reflects factors that the government may use in making the national tourism policy as it covers the overall travel and tourism industry of a country, but it does not reflect the competitiveness of the tourism SMEs.

Table 3:-Summary On Elements Of Tourism Competitiveness

\begin{tabular}{|l|c|}
\hline \multicolumn{1}{|c|}{ Elements/factors, nature } & \multicolumn{1}{|c|}{ Quoted/studied by } \\
\hline $\begin{array}{l}\text { 1. Access/destination accessand connectivity: infrastructure, } \\
\text { geo-strategic position and proximity }\end{array}$ & $\begin{array}{c}\text { OECD (2012), Ritchie and Crouch (2003), } \\
\text { World Economic Forum (2013) }\end{array}$ \\
\hline $\begin{array}{l}\text { 2. Activities/attraction, tourism product, special events, } \\
\text { entertainment development/mix of activities: gastronomy, } \\
\text { product differentiation, innovation, unique experience } \\
\text { provision }\end{array}$ & $\begin{array}{c}\text { OECD (2012), Ritchie and Crouch (2003), } \\
\text { Morgan, et. al. (2011) }\end{array}$ \\
\hline $\begin{array}{l}\text { 3. Cultural, historic and natural edge: physiography and } \\
\text { climate biodiversity, gastronomy, sustainability }\end{array}$ & $\begin{array}{c}\text { Ritchie and Crouch (2003), OECD (2012), } \\
\text { UNWTO (2012), World Economic Forum (2013) }\end{array}$ \\
\hline $\begin{array}{l}\text { 4. Destination branding: identity image, destination } \\
\text { awareness, market diversification, promotion and marketing }\end{array}$ & $\begin{array}{c}\text { OECD (2012),UNWTO (2012) } \\
\text { Kotler (2006) }\end{array}$ \\
\hline
\end{tabular}




\begin{tabular}{|l|l|}
\hline \multicolumn{1}{|c|}{ Elements/factors, nature } & \multicolumn{1}{c|}{ Quoted/studied by } \\
\hline $\begin{array}{l}\text { 5. Human resources development: education, talent } \\
\text { development and training, skill, labor productivity, tourism } \\
\text { training centers }\end{array}$ & $\begin{array}{l}\text { OECD (2012), Asian Development Bank } \\
\text { Institute (2014), World Travel and Tourism } \\
\text { Council (2014), World Economic Forum (2013), } \\
\text { Royal Thai Government (2014) }\end{array}$ \\
\hline $\begin{array}{l}\text { 6. Market ties: ethnic ties, visiting friends and relatives (VFR), } \\
\text { business, religion, sport, trade and cultural tie }\end{array}$ & $\begin{array}{l}\text { Ritchie and Crouch (2003), OECD (2012), } \\
\text { Dupeyras and MacCallum (2013), Dwyer and Kim } \\
\text { (2003) }\end{array}$ \\
\hline $\begin{array}{l}\text { 7. Quality of tourism services: quality improvement, } \\
\text { hospitality, quality of life, social equity and cohesion, services } \\
\text { to customers }\end{array}$ & $\begin{array}{l}\text { OECD (2012), Ascot and Bernard quotedin } \\
\text { Rupjumlong (2009), World Economic } \\
\text { Forum(2013) }\end{array}$ \\
\hline $\begin{array}{l}\text { 8. Price competitiveness: prices, exchange rates, ratio of } \\
\text { price/quality or value-for money }\end{array}$ & $\begin{array}{l}\text { Ritchie and Crouch (2003), World Economic } \\
\text { Forum(2013) }\end{array}$ \\
\hline $\begin{array}{l}\text { 9. Tourism superstructure: accommodation facilities, } \\
\text { foodservices, transportation facilities and major attractions }\end{array}$ & $\begin{array}{l}\text { OECD (2012), World Economic Forum (2013), } \\
\text { Choibamroong (2014) }\end{array}$ \\
\hline $\begin{array}{l}\text { 10. Tourism governance: prioritization of tourism, } \\
\text { government support, tourism strategy, safety and data, budget } \\
\text { allocation, institutions (e.g. national tourism board), } \\
\text { multilateral cooperation, allocation of resources and workforce, } \\
\text { tourism crisis management plans and strategies }\end{array}$ & $\begin{array}{l}\text { Glaesser (2003), World Economic Forum } \\
\text { (2013) }\end{array}$ \\
\hline
\end{tabular}

Source: Adapted from Dupeyras and MacCallum (2013: 14-17)

\section{The Travel and Tourism Competitiveness Index}

The World Economic Forum's Travel and Tourism Competitiveness Index (World Economic Forum, 2013) revealed that the travel and tourism competitiveness of 140 economies in all regions globally included three sub-indexes as follows: 1) the travel and tourism regulatory frame work, 2) the travel and tourism business environment and infrastructure, and 3) the travel and tourism human, cultural, and natural resources. The three sub-indexes comprised 14 pillars, based on the results derived from the executive opinion survey and quantitative data from other sources.

The World Economic Forum, however, revised the sets of the Travel and Tourism Competitiveness Index (TTCI) for the year 2013 (World Economic Forum, 2015) by re-categorizing the sub-indexes as shown on the table 4 on page 12 as follows : 1) enabling environment, comprising business environment, safety and security, health and hygiene, human resources and labor market, and ICT readiness, 2) $\mathrm{T}$ and $\mathrm{T}$ policy and enabling conditions, comprising prioritization of travel and tourism, international openness, price competitiveness, and environmental sustainability, 3) infrastructure; comprising air transport infrastructure, ground and port infrastructure, and tourist service infrastructure, and 4) natural and cultural resources, comprising natural resources, cultural and business travel. Thailand ranked the first for the tourist service infrastructure pillar, and natural resources pillar, but ranked the ninth for the safety and security pillar among 9 ASEAN member countries, having been covered in the report.

Ritchie and Crouch (1999) regarded the destination experience as the fundamental tourism product, and the tourism competition was destination-centered. The tourism products and services are mainly provided by SMEs, thus the tourism destination's competitiveness reflects the local tourism SMEs' competitiveness. Crouch's perspective on each tourism destination's unique position and its development goal was well emphasized, for example tourism in Bhutan government adopted the tourism policy, aiming to attract high value tourists with low volume of international tourist arrivals (Dorji, n.d.). Bhutan tourism development aimed to generate foreign currency revenue, and the country's socio-economy envisaged the tourism impacts and adopted cautious measures to control the quantity and type of tourism.

With reference to certain TTCI sub-indexes, in particular the T and T regulatory framework, they might not actually reflect the accurate competitiveness since a country's tourism policy may be different from others on the same matters, taking into consideration what the country needs to achieve and/or avoid. Bhutan aimed to protect the country's natural environment and tourism resources, therefore, Bhutan's laws were stipulated to prevent overcrowding tourism, and encourage the value, not the volume, of the tourists' arrival. 
An assessment of a nation's tourism competitiveness should be conducted, based on its capacity to achieve its own particular goals, rather than assuming that all countries' tourism goals were the same (Crouch, n.d.). Therefore, the tourism policy framework of a country might not be so open and enabling as expected by other countries.

Table 4:-The Travel and Tourism Competitiveness Index of Thailand, Year 2013 comparing with other ASEAN member countries*

\begin{tabular}{|c|c|c|c|c|c|c|c|c|c|}
\hline & Thailand & Malaysia & Singapore & Indonesia & Vietnam & Philippines & Cambodia & $\begin{array}{l}\text { Lao } \\
\text { PDR }\end{array}$ & Myanmar \\
\hline & $\begin{array}{c}\text { Rank in } \\
\text { ASEAN } \\
\text { / } \\
\text { Global } \\
\text { Rank }\end{array}$ & $\begin{array}{c}\text { Rank in } \\
\text { ASEAN } \\
/ \\
\text { Global } \\
\text { Rank }\end{array}$ & $\begin{array}{c}\text { Rank in } \\
\text { ASEAN } \\
/ \\
\text { Global } \\
\text { Rank }\end{array}$ & $\begin{array}{c}\text { Rank in } \\
\text { ASEAN } \\
/ \\
\text { Global } \\
\text { Rank }\end{array}$ & $\begin{array}{c}\text { Rank in } \\
\text { ASEAN } \\
\text { / } \\
\text { Global } \\
\text { Rank }\end{array}$ & $\begin{array}{c}\text { Rank in } \\
\text { ASEAN / } \\
\text { Global } \\
\text { Rank }\end{array}$ & $\begin{array}{c}\text { Rank in } \\
\text { ASEAN } \\
/ \\
\text { Global } \\
\text { Rank }\end{array}$ & $\begin{array}{c}\text { Rank in } \\
\text { ASEAN } \\
\text { / } \\
\text { Global } \\
\text { Rank }\end{array}$ & $\begin{array}{c}\text { Rank in } \\
\text { ASEAN } \\
\text { / } \\
\text { Global } \\
\text { Rank }\end{array}$ \\
\hline The Overall TTCI & $3 / 35$ & $2 / 25$ & $1 / 11$ & $4 / 50$ & $6 / 75$ & $5 / 74$ & $8 / 105$ & $7 / 96$ & $9 / 134$ \\
\hline $\begin{array}{l}\text { 1) Enabling } \\
\text { environment }\end{array}$ & $4 / 74$ & $2 / 40$ & $1 / 5$ & $5 / 80$ & $3 / 73$ & $7 / 90$ & $8 / 105$ & $6 / 84$ & $9 / 131$ \\
\hline $\begin{array}{l}1.1) \text { Business } \\
\text { environment }\end{array}$ & $3 / 38$ & $2 / 10$ & $1 / 1$ & $6 / 63$ & $7 / 66$ & $5 / 60$ & $8 / 129$ & $4 / 56$ & $9 / 135$ \\
\hline 1.2) Safety and security & $9 / 132$ & $2 / 42$ & $1 / 8$ & $5 / 83$ & $4 / 75$ & $8 / 128$ & $6 / 92$ & $3 / 56$ & $7 / 125$ \\
\hline $\begin{array}{l}\text { 1.3) Health and } \\
\text { hygiene }\end{array}$ & $4 / 89$ & $2 / 73$ & $1 / 61$ & $8 / 109$ & $3 / 83$ & $5 / 91$ & $9 / 112$ & $7 / 108$ & $6 / 101$ \\
\hline $\begin{array}{l}\text { 1.4) Human resources } \\
\text { and labor market }\end{array}$ & $2 / 29$ & $3 / 30$ & $1 / 3$ & $4 / 53$ & $5 / 55$ & $6 / 62$ & $8 / 72$ & $7 / 67$ & $9 / 117$ \\
\hline 1.5) ICT readiness & $3 / 60$ & $2 / 54$ & $1 / 1$ & $4 / 85$ & $6 / 97$ & $5 / 86$ & $7 / 102$ & $8 / 106$ & $9 / 140$ \\
\hline $\begin{array}{l}\text { 2) } T \text { and } T \text { policy and } \\
\text { enabling conditions: }\end{array}$ & $5 / 49$ & $4 / 24$ & $1 / 1$ & $2 / 9$ & $8 / 112$ & $3 / 17$ & $6 / 64$ & $7 / 80$ & $9 / 136$ \\
\hline $\begin{array}{l}\text { 2.1) Prioritization of } \\
\text { travel and tourism }\end{array}$ & $5 / 40$ & $7 / 56$ & $1 / 4$ & $2 / 15$ & $9 / 119$ & $3 / 27$ & $4 / 37$ & $6 / 50$ & $8 / 108$ \\
\hline $\begin{array}{l}\text { 2.2) International } \\
\text { openness }\end{array}$ & $4 / 49$ & $3 / 46$ & $1 / 1$ & $5 / 55$ & $8 / 89$ & $2 / 29$ & $6 / 59$ & $7 / 76$ & $9 / 120$ \\
\hline $\begin{array}{l}\text { 2.3) Price } \\
\text { competitiveness }\end{array}$ & $5 / 36$ & $2 / 6$ & $8 / 116$ & $1 / 3$ & $3 / 22$ & $4 / 24$ & $6 / 40$ & $7 / 48$ & $9 / 125$ \\
\hline $\begin{array}{l}\text { 2.4) Environmental } \\
\text { sustainability }\end{array}$ & $4 / 116$ & $6 / 119$ & $1 / 51$ & $9 / 134$ & $8 / 132$ & $7 / 122$ & $5 / 118$ & $3 / 112$ & $2 / 110$ \\
\hline 3) Infrastructure: & $2 / 37$ & $3 / 41$ & $1 / 5$ & $4 / 75$ & $6 / 94$ & $5 / 82$ & $8 / 113$ & $7 / 100$ & $9 / 137$ \\
\hline $\begin{array}{l}\text { 3.1) Air transport } \\
\text { infrastructure }\end{array}$ & $2 / 17$ & $3 / 21$ & $1 / 6$ & $4 / 39$ & $6 / 68$ & $5 / 67$ & $8 / 103$ & $7 / 89$ & $9 / 115$ \\
\hline $\begin{array}{l}\text { 3.2) Ground and port } \\
\text { infrastructure }\end{array}$ & $3 / 71$ & $2 / 35$ & $1 / 2$ & $4 / 77$ & $5 / 87$ & $6 / 93$ & $8 / 116$ & $7 / 96$ & $9 / 132$ \\
\hline $\begin{array}{l}\text { 3.3) Tourist service } \\
\text { infrastructure }\end{array}$ & $1 / 21$ & $3 / 68$ & $2 / 34$ & $6 / 101$ & $7 / 105$ & $4 / 82$ & $8 / 108$ & $5 / 97$ & $9 / 137$ \\
\hline $\begin{array}{l}\text { 4) Natural and } \\
\text { cultural resources: }\end{array}$ & $2 / 21$ & $3 / 24$ & $5 / 40$ & $1 / 17$ & $4 / 33$ & $6 / 56$ & $7 / 82$ & $9 / 94$ & $8 / 87$ \\
\hline 4.1) Natural resources & $1 / 16$ & $3 / 26$ & $6 / 69$ & $2 / 19$ & $4 / 40$ & $5 / 49$ & $7 / 70$ & $8 / 77$ & $9 / 80$ \\
\hline $\begin{array}{l}\text { 4.2) Cultural } \\
\text { resources and } \\
\text { business travel }\end{array}$ & $5 / 34$ & $3 / 27$ & $1 / 22$ & $2 / 25$ & $4 / 33$ & $6 / 62$ & $7 / 76$ & $9 / 113$ & $8 / 92$ \\
\hline
\end{tabular}

Source : Compiled from The Travel and Tourism Competitiveness Report 2015, retrieved from http://www

3.weforum.org, pp.324-325, 224-225, 298-299, 180-181, 344-345, 272-273, 108-109, 206-207, and 246247.

*The Report covered 141 countries, but Brunei Darussalam was not covered in the Report.

\section{Overview of AEC 2015: AEC's liberalized trade in services}

The ASEAN Economic Community (AEC) was declared as the goal of the regional economic integration by 2015 to establish a prosperous, stable and highly competitive ASEAN economic region for a free flow of goods, services, investment and a freer flow of capital, equitable economic development and reduced poverty and socio-economic disparities in year 2020, (Bali Concord II, 2003, cited in ASEAN Integration in Services, 2009). 
The AEC comprises 10 ASEAN member countries: Brunei Darussalam, the Kingdom of Cambodia, the Republic of Indonesia, the Lao People's Democratic Republic, Malaysia, the Union of Myanmar, the Republic of the Philippines, the Republic of Singapore, the Kingdom of Thailand the Socialist Republic of Viet Nam. The Declaration of the ASEAN Economic Community Blueprint (ASEAN, 2008) specified the goal to broaden and deepen ASEAN economic integration with no restriction to the ASEAN service suppliers in providing services and establishing business entities across the national border within ASEAN, but subject to each member's laws and regulations.

The World Trade Organization (WTO) allowed members to operate measures regarding access to employment, citizenship or residence as per the Annex on Movement of Natural Persons (GATS, 1995). All ASEAN member countries have now been members of WTO, thus subject to WTO's rules and regulations. ASEAN member countries have been additionally committed under ASEAN Free Trade Agreement in Services (AFAS), and subject to allow the free flow of services and immigration of skilled labors.

\begin{tabular}{|c|c|c|c|}
\hline & \multicolumn{2}{|c|}{ GATS' Modes of Services Supply } & \\
\hline $\begin{array}{c}\text { Mode 1: } \\
\text { Cross border } \\
\text { supply }\end{array}$ & $\begin{array}{c}\text { Mode 2: } \\
\text { Consumption } \\
\text { aboard }\end{array}$ & $\begin{array}{c}\text { Mode 3: } \\
\text { Commercial } \\
\text { presence }\end{array}$ & $\begin{array}{c}\text { Mode4: } \\
\text { Presence of } \\
\text { natural persons }\end{array}$ \\
\hline \multirow[t]{2}{*}{$\begin{array}{l}\text { Services move } \\
\text { across border: } \\
\text { - Architectural } \\
\text { services } \\
\text { - Banking services } \\
\text { transmitted via } \\
\text { mails or } \\
\text { telecommunications }\end{array}$} & $\begin{array}{l}\text { Consumers move } \\
\text { across border to } \\
\text { obtain services: } \\
\text {-Tourists } \\
\text {-Patients move } \\
\text { across border for } \\
\text { medical services in } \\
\text { another member }\end{array}$ & \multirow[t]{2}{*}{$\begin{array}{l}\text { Service providers } \\
\text { of a member move } \\
\text { across border to } \\
\text { render services in } \\
\text { another member's } \\
\text { territory with a } \\
\text { commercial } \\
\text { establishment: }\end{array}$} & $\begin{array}{l}\text { Persons who are } \\
\text { service providers of } \\
\text { a country move } \\
\text { across border to } \\
\text { provide services } \\
\text { temporarily or } \\
\text { occasionally: } \\
\text { - Doctors }\end{array}$ \\
\hline & $\begin{array}{c}\text { Increasing } \\
\text { Intra-regional } \\
\text { tourism }\end{array}$ & & $\begin{array}{l}\text { - Teachers } \\
\text { - Accountants } \\
\text { - Other }\end{array}$ \\
\hline
\end{tabular}

Figure 1:-GATS' Modes of Services Supply

Source: General Agreement on Trade of Services, WTO (1995)

The Mutual Recognition Agreement on Tourism Professionals (ASEAN, 2012), provided a mechanism for tourism certification procedures and qualifications standards to encourage a free-flow of tourism labor across ASEAN. The tourism professionals of a member state, having a valid tourism competency certificate as agreed and accepted by the ASEAN nations, will be eligible to move across the border to render services or work in another ASEAN member country, subject to the local rules and laws.

Strategies for enhancing tourism SMEs' competitiveness

The AEC's liberalized trade in services would attract increasing intra-regional tourism, and international tourist arrival. The tourism SMEs, rendering services at destinations, would face rising competition as the tourists would have access to many more choices. The tourism service provider SMEs, tourism professionals and skilled labors 
have ample opportunities to move across border to provide services temporarily or occasionally. There would also be rising migration of skilled labor from other ASEAN member countries into Thailand tourism sector. The Thai tourism workers and SMEs need to adapt to the change by learning more about ASEAN and the global tourism trend, find opportunities to collaborate with the regional tourism network to strengthen and/or expand their business capabilities, and make good use of ICT for their business management and internationalization.

The Thai government had recognized the tourism's significant impacts on Thailand economy. Despite of the high volume of the international tourist arrival and international receipts, the tourism revenue was mostly earned by large enterprises in main tourism sectors: accommodations, food and beverage, land transport and sale of souvenirs for over 80 percent of the total tourism revenue (Wattanakuljarus, et al., 2014). To enhance tourism SMEs' competitiveness, the Thai government, government agencies, especially tourism policy makers and implementers, should be well aware of the unique nature of the tourism SMEs, which is different from SMEs of trade in goods. We recommend the following strategies:

To adopt proactive strategies, and take into consideration the tourism competitiveness elements: easy success, good tourism superstructure, quality of tourism services, value-for money products and services, unique attractions, and activities, cultural, historical and natural edge to build a market tie with visitors, based on the sustainability principles to ensure that there would be no present and future socio-economic, political and environmental impacts on the tourism destinations, local communities and the overall national tourism.

To develop tourism human capital in both private and public sectors, by providing sufficient education with English competency, and other ASEAN languages proficiency with trainings on AEC, tourism knowledge, ICT, and intercultural understanding. The public sector should be well trained to be capable to help support tourism SMEs and tourism service providers at destinations.

To empower and equip the government agencies at destinations with the ICT access to facilitate tourism management and strengthen their capabilities to enhance local tourism SMEs with updated information and measures to encounter emergency and suppress troubles.

To develop and maintain tourism destinations by continuously promoting environmental awareness among the host communities, local tourism service providers and visitors. The tourism SMEs should be encouraged to address their care for the planet and their visitors.

To enable the tourism SMEs to have access to finance at low costs so that they have funds to increase their services quality, create the unique value to their business and innovation in their tourism services and products.

The tourism SMEs without competitive tourism talents and skills would face a difficult time to compete in a fiercer market: the stronger and efficient support of the government and public sector is required. Further studies should focus on the development of tourism talents and skills training for the young generation and adults so that Thailand tourism SMEs in the next generation is properly prepared, and the issue of innovation in tourism products and services should also be addressed.

\section{References:-}

1. Asian Development Bank Institute. (2014). ASEAN 2030 Toward a Borderless Economic Community. Japan. Retrieved from http:/www.adbi.org

2. ASEAN. (1995). ASEAN Framework Agreement on Services. Retrieved from http://www.asean.org

3. ASEAN. (2008). ASEAN Economic Community Blueprint. Jakarta: ASEAN Secretariat.

4. ASEAN. (2011). Directory of Outstanding ASEAN SMEs 2010. Jakarta: ASEAN Secretariat.

5. ASEAN. (2012). ASEAN Mutual Recognition Arrangement on Tourism Professionals. Retrieved from http://www.aseantourism.travel

6. ASEAN. (2013).SME Guidebook Towards the AEC 2015. Jakarta: ASEAN Secretariat.

7. Braun. (2005). Creating Value to Tourism Products Through Tourism Network and Clusters: Uncovering Destination Value Chains. Retrieved fromhttp://www.cecc.com.au

8. Choibamroong, T. (2014). NIDA Model, Thailand Reform: Guidelines for Tourism Reform. Bangkok: National Institute of Development Administration. 
9. Crouch and Ritchie.(1999). Tourism Competitiveness, and Societal Prosperity. Journal of Business Research 44, 137-152.

10. Crouch, G. (n.d). Measuring Tourism Competitiveness: Research, Theory and the WEF Index. Retrieved from http://www.anzmac.org

11. Department of Tourism. (2012). 2012-2017 Tourism and Travel Related Services Strategic Plan-Responding to the ASEAN Services Liberalization. Bangkok: Thailand.

12. Dorji, T. (n.d.) Sustainability of Tourism in Bhutan. Journal of Bhutan Studies. Retrieved from http://www.himalaya.soconth.cam.ac.uk

13. Dwyer and Kim. (2003). Destination Competitiveness: Determinants and Indicators. Retrieved from http://www.reseaschgate.net

14. Dupeyras and MacCallum. (2013). Indicators for Measuring Competitiveness in Tourism: A Guidance Document. OECD Publishing. Retrieved from http://dx.doi.org

15. Glaesser, D. (2003). Crisis Management in the Tourism Industry. UK: Elsevier Butterworth Heinemann.

16. International Labour Organization. (2010). Developments and Challenges in the Hospitality and Tourism Sector. Retrieved from http://www.ilo.org

17. Egger and Smith. (1997). Meta-analysis: Potentials and Promise. British Medical Journal, 315 (7119), 13711374. Retrived from http://www.massey.ac.nz

18. Keller, P. (2004). The Future of Small and Medium Size Enterprises in Tourism. Retrieved from http://worldcat.org

19. Kotler, P. (2006). Marketing for Hospitality and Tourism. NJ: Pearson Education Ltd.

20. Marzano, R. (1998). A Theory-Based Meta-Analysis of Research on instruction. Retrieved from http://www.faculty.mun.ca

21. Morgan, et al. (2011). Destination Brands: Managing Place Reputation. ( $3^{\text {rd }}$ ed.). GB: Elsevier.

22. Noel, et al. (2010). Helping Tourism SMEs Plan and Implement Information and Communication Technology. Retrieved from http://www.iby.it

23. OECD. (n.d.) Members and Partners. Retrieved from http:// www.oecd.org

24. OECD. (2011). OECD Studies on SMEs and Entrepreneurship: Thailand Key Issues and Policies. OECD Publishing. Retrieved from http://www.dxdoi.org

25. OECD. (2013). Measuring the Internet Economy: A Contribution to the Research Agenda, OECD Digital Economy Papers No. 226. OECD Publishing. Retrieved fromhttp://www.dx.doi.org

26. Office of SMEs Promotion. (n.d.) The 2nd SMEs Promotion Plan (2007-2011). Retrieved from http://www.sme.go.th

27. Poon, A. (1993).Tourism, Technology and Competitive Strategies. Wallingford, UK: CAB International.

28. Porter, M. (2008). The Five Competitive Forces That Shape Strategy. Harvard Business Review. Retrieved from http://www.exed.hbs.edu

29. Porter, M. (1990). The Competitive Advantage of Nations. HK: The Macmillion Press Ltd. Ritchie and Crouch. (2003). The Competitive Destination: A Sustainable Tourism Perspective. UK: CABI Publishing.

30. Royal Thai Government. (2014). SMEs Promotion Approved as National Agenda. Retrieved from http://www.thaigov.go.th

31. Rupjumlong, P. (2009). The Strategic Policy Framework for Health/Wellness Tourism Promotion of Thailand. Bangkok: The National Institute of Development Administration.

32. Smeral, E. (1998). The Impact of Globalization on Small and Medium Enterprises: New Challenges for Tourism Policies in European Countries. UK: Elsevier Ltd.

33. Sriburi, et al. (2007).Sustainable Tourism Management in Thailand: A Good Practices Guide for SMEs. Thailand: Environmental Research Institute of Chulalongkorn University and Bumi Kita Foundation.

34. Thailand Management Association. (2013). Comparative Study on Policies and Measures Responding to the ASEAN Economic Community for SMEs in ASEAN member countries. Bangkok: Office of SMEs Promotion.

35. Theoleyre and d'Istria Owen. (2013). External Evolution of UNCTAD Project Account- Strengthening SMEs Competitiveness in the Tourism Sector of Six Developing Countries of the ECOWAS sub region. Retrieved from http://www.unctad.org

36. UNWTO. (2014). UNWTO Tourism Highlights 2014 Edition. Retrieved from http://www.unwto.org

37. UNWTO. (2013). Tourism Towards 2030: Global Overview. Retrieved from http://www.wise.co.th

38. Wattanakuljarus, et al. (2014). NIDA Model, Thailand Reform: Suggestions on Distribution of Thailand Tourism Revenue. Bangkok: National Institute of Development Administration.

39. Wong, et al. (2009).Understanding ASEAN Tourism Collaboration-the Preconditions and Policy Framework Formulation. International Journal of Tourism Research. Retrieved from http:/interscience.wiley.com 
40. World Economic Forum. (2012). The ASEAN Travel andTourism Competitiveness Report 2010: Fostering Prosperity and Regional Integration Through Travel and Tourism. Retrieved from http://www.weforum.org

41. World Economic Forum. (2013). The Travel andTourism Competitiveness Report 2013: Reducing Barriers to Economic Growth and Job Creation. Retrieved from http://www.weforum.org

42. World Economic Forum. (2015). The Travel and Tourism Competitiveness Report 2015: Growth through Shocks. Retrieved fromwww.weforum.org

43. World Trade Organization. (1995). The General Agreement on Trade in Services. Retrieved from http://www.wto.org

44. World Travel and Tourism Council. (2014). Travel and Tourism World Economic Impact 2014. Retrieved from www.wttc.org. 